Tér és Társadalom 17. évf. 2003/4. 195-197. p.

Tér és Társadalom

XVII. évf. 2003 4: 195-197

\title{
KÖNYVJELZÖ
}

\section{SZENYÉRI ZOLTÁN: A TOLNA ÉS A BARANYA MEGYEI NÉMETEK SORSA A BETELEPÍTÉSEKTŐL NAPJAINKIG}

\author{
(Dombóvári Német Kisebbségi Önkormányzat, \\ Dombóvár, 2002, 250 o.)
}

\section{KUGLER JÓZSEF}

A könyv címe leginkább a történészek és a nemzetiségi (kisebbségi) kérdések iránt érdeklődők figyelmét keltheti fel. Elegendő azonban egy rövid áttekintés vagy csak egyszerủ átlapozás is ahhoz, hogy a geográfusok és a regionális tudomány művelöi is felfedezzék a kötetet a maguk számára.

Szenyéri Zoltán a Debreceni Tudományegyetem történelem-földrajz szakán szerzett diplomát, és jelenleg is választott hivatását gyakorolja Dombóváron. A könyv lényegében a szerző $\mathrm{PhD}$ értekezése, amelynek anyagát tanári munkája mellett, többéves alapos kutatással állította össze a Pécsi Tudományegyetem Földrajzi Intézete doktori iskolája hallgatójaként. Így e dolgozat is méltó folytatása a nyolcvanas évektöl újjáéledő honi etnikai térszerkezeti kutatásoknak, illetve az e témakörben megjelent munkáknak.

A tanulmány a 18. század elsỏ évtizedeitől a 20. század végéig kíséri figyelemmel a két dunántúli megye németsége sorsának alakulását. A Kárpát-medence újkori nemzetiségi-etnikai viszonyainak alakulására (mint közismert) csaknem napjainkig döntó hatással volt a 18. századi újratelepítés, melynek során a török uralom alól felszabadított, többnyire igen gyér népességủ területeken a magyarság mellett más etnikumok is megtelepedtek. Egyik ilyen jellegzetes többnyelvű és kultúrájú térsége a mai Magyarországnak a Dél-Dunántúl (Baranya és Tolna megye). A német geográfiai és néprajzi szakirodalom által félig-meddig tréfásan Schwäbische Türkeinek nevezett vidéken élt a trianoni országterület közel félmilliós németségének több mint harmada. Az említett országrészen belül is jól elkülöníthetőek azok a kistérségek, ahol a németség a második világháború végéig a lakosság döntő hányadát alkotta. Így a Sió és a Kapos által közrefogott dombsági jellegü Völgységet, valamint a Pécs városát északi és keleti irányból körülvevő baranyai településövet sorolhatjuk ide. Ugyancsak jól kirajzolódnak azok a településcsoportok is, ahol a németek mellett magyarokat, horvátokat és szerbeket is találunk. E térbeli elhelyezkedés három évszázados változásainak bemutatását tủzte ki célul Szenyéri Zoltán, aki (mint ezt bevezetöjében is jelezte) nem a térség németsége történetének monog- 
Tér és Társadalom 17. évf. 2003/4. 195-197. p.

rafikus feldolgozására vállalkozott, hiszen ezt a feladatot csak a jelenleginél jóval nagyobb terjedelemben végezhette volna. Sokkal inkább az említett népcsoport sorsának alakulását bemutatva az etnikai térszerkezet módosulásait helyezte elötérbe, vagyis a történeti részek inkább csak tájékoztató jellegủek, elsősorban a térbeli folyamatok alaposabb megértését segítik.

A hét fejezetből álló, a mellékletekkel együtt közel 250 oldalas tanulmány első lapjai rövid tudománytörténeti áttekintést nyújtanak az olvasónak a honi etnikai kutatásokról, és megvilágítják a feldolgozás néhány módszertani kérdését is. A fö részek (a negyediktől a hetedik fejezetig) pedig időrendben a térségben élő németség etnikai térszerkezetének alakulását elemzik kellő alapossággal. A németek közel háromszáz éves dél-dunántúli jelenlétét négy szakaszra bontja az értekezés. $\mathrm{Az}$ újratelepítéstỏl a 19. század közepéig terjed idörendben az első periódus, majd ezt követi a második, a 19. század közepétöl a második világháborúig (1941-ig). Az 1944 és 1948 közötti néhány esztendő jelenti a harmadik szakaszt, végül a negyedik 1948-tól napjainkig tart. Az egyes időszakaszok határait a szerző részben a rendelkezésre álló adatbázis, részben pedig a történelmi-politikai események figyelembevételével jelölte ki.

Egy-egy országban (régióban) élő nemzetiségi (kisebbségi) lakosság lélekszámát, területi elhelyezkedését számos tényező befolyásolhatja. Így egyebek mellett meghatározó lehet a többségi nemzet (állam) kisebbségpolitikája, illetve az adott kisebbségnek e politikára adott válasza, elutasítja vagy pedig kénytelen-kelletlen, esetleg szívvel-lélekkel elfogadja a többségi nemzet által szorgalmazott asszimilációs tendenciák érvényesülését. Ugyancsak számításba veendő a nemzetközi politikai háttér: az erős vagy gyenge anyaország léte és érdeklődése a határon túli kisebbségei iránt, a nemzetközi kisebbségvédelmi egyezmények érvényesülése, esetleg a nemzetközi érdektelenség tartóssága e téren. A gazdasági és társadalmi átalakulás (urbanizáció) és a politikai okok miatt történő önkéntes vagy kényszermigráció is jelentős módosulást okozhat egy-egy térség (állam) etnikai összetételében csakúgy, mint az államilag támogatott telepítéspolitika. Mindezek és még további más tényezök évtizedes (évszázados) hatásai érvényesülnek a dél-dunántúli németek lélekszámának és területi elhelyezkedésének alakulásában is.

A kutató rendelkezésére álló adatbázis vizsgált időszakonként más és más. A késő feudalizmus évtizedeire vonatkozó, nyomtatásban is közre adott történeti statisztikai források, hivatalos népszámlálási adatok és saját felmérési eredmények egyaránt a részét képezik a felhasznált adatbázisnak. A szerző szerkesztési, feldolgozási módszere a tanulmány egészén jól nyomon követhetỏ: egy-egy periódus kisebbségi vonatkozásairól rövid országos és térségi áttekintést ad, majd pedig a korszak számszerüsíthetô változásait ábrázolja térképen. Az alaptérkép a jelenlegi közigazgatási beosztás szerinti Baranya és Tolna megye, a bekövetkező változásokat, az etnikai arányok módosulását, illetve ezek településenkénti változását visszamenőleg is e térképeken ábrázolja, ennélfogva összehasonlíthatók a végbemenő folyamatok. 
Szenyéri Zoltán az említett adatbázis mellett széles skálájú szakirodalmat is felhasznált. A magyarországi és dél-dunántúli németség történetére, illetve e kisebbség egyes korszakaira (kitelepítés) vonatkozó honi munkák mellett, természetszerủleg, jelentős számú a hivatkozott hazai és a külföldi (német nyelvü) szakirodalom is. A további információszerzéshez, legfő́képpen pedig a második világháborút követő népességmozgások számszerüsítéséhez nélkülözhetetlenek a településmonográfiák. A szöveg megértését, a térbeli folyamatok három évszázados alakulását közel harminc táblázat és több mint ötven ábra segíti. A könyv mondanivalója szempontjából is kiemelkedőek azok a színes térképek, amelyek több idökeresztmetszetben tárják az olvasó elé a németség területi elhelyezkedését, és adnak számot a második világháborút követố évek migrációjáról, ami leginkább hatást gyakorolt az etnikai térszerkezet alakulására. Így magyarázatot kapunk egyúttal arra is, miért „erőtlenedett el” az egykoron népes tolnai német tömb, és tarthatta meg (valamelyest meggyengülve ugyan) korábbi etnikai jellegét Kelet-Baranya.

A második világháborút követö népességmozgásokról (ki- és betelepítésekről) az utóbbi másfél-két évtizedben egyre több tanulmány látott napvilágot. Ennek ellenére föleg a vándorlási mérleg településenkénti számsorai még mindig pótlásra szorulnak. Ugyancsak hiányosak az ismereteink arról, hogy a történelmi traumák hatására miként alakult a hazai (dél-dunántúli) németek identitása, az anyanyelv továbbélése, a kapcsolattartás a külföldön élö rokonokkal. Az 1980. évi hivatalos népszámlálási eredményeket a Hoóz István vezette munkacsoport az ún. tanácsi minösítések alapján kísérelte meg korrigálni, vagyis községenként számba venni, hogy a bevallottakon kívül élnek-e még az adott településen nemzetiségiek. A szerző ugyancsak kérdőíves felmérés segítségével igyekezett újabb számszerüsíthető információkat szerezni. Mintatelepüléseket választott, vagyis városok és aprófalvak, egykoron erősen német többségü, illetve vegyes lakosságú települések egyaránt szerepeltek a vizsgált helységek között. Felmérése eredményeit a 7. fejezetben összegezte, megállapítva egyebek mellett, hogy német anyanyelvüket inkább az idösebb korosztályok vállalják, ugyanakkor új jelenségként előfordulnak olyan települések is, ahol a német nemzetiségủek száma felülmúlja a német anyanyelvủekét.

A jelenleg is formálódó honi régiókra és kistérségekre a területfejlesztési feladatok megoldásában (mint közismert) az elkövetkezendő években az eddigieknél is nagyobb szerep hárul. Ehhez pedig elengedhetetlen a régiók (kistérségek) minél alaposabb ismerete, a rendelkezésre álló természeti és humán eróforrások sokoldalú feltárása. Ez utóbbihoz járul hozzá az ismertetett kötet is. A szerző ígérete szerint elemzéseit rövidesen kiterjeszti a Somogy megyei településekre is, és így a Déldunántúli régió németsége etnika térszerkezetét, illetve annak időbeli változásait feltáró munka teljessé válik. 